Primljen / Received: 1.2.2012.

Ispravljen / Corrected: 4.5.2012.

Prihvaćen / Accepted: 11.5.2012.

Dostupno online / Available online: 25.5.2012.

\section{Analysis of buildings operation and maintenance costs}

Authors:

Subject review

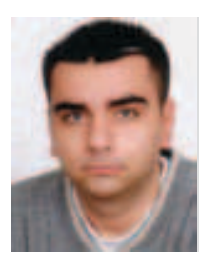

Hrvoje Krstić, PhD. CE

University J.J. Strossmayera of Osijek

Faculty of Civil Engineering

hrvojek@gfos.hr

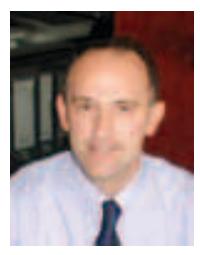

Prof. Saša Marenjak, PhD. CE University J.J. Strossmayera of Osijek Faculty of Civil Engineering sasa.marenjak@zg.htnet.hr

\section{Hrvoje Krstić, Saša Marenjak}

\section{Analysis of buildings operation and maintenance costs}

The research presented in the paper is aimed at determining possibilities for collecting historic data on the maintenance and use of buildings of the Josip Juraj Strossmayer University in Osijek. Surveys and questionnaires were prepared and used to collect data about the above mentioned costs, as well as the data on the properties of buildings, and on the way in which they were used for a defined time period. The data collected in this way were statistically analyzed and presented in this paper.

\section{Key words:}

costs of maintenance and use of buildings, structure of costs, mathematical model, statistically significant variables varijable

Pregledni rad

\section{Hrvoje Krstić, Saša Marenjak}

\section{Analiza troškova održavanja i uporabe gradevina}

Istraživanje u ovome radu usmjereno je na utvrđivanje mogućnosti prikupljanja povijesnih podataka o troškovima održavanja i uporabe gradevina Sveučilišta Josipa Jurja Strossmayera u Osijeku. Sastavljene su ankete i upitnici kojima su se prikupljali podaci o navedenim troškovima, kao i podaci o karakteristikama građevina i načinima uporabe za definirano vremensko razdoblje. Prikupljeni su podaci statistički obrađeni i prikazani u ovome radu.

Ključne riječi:

troškovi održavanja i uporabe gradevina, struktura troškova, matematički model, statistički značajne

\section{Hrvoje Krstić, Saša Marenjak}

Übersichtsarbeit

\section{Kostenanalyse der Instandhaltung und Verwendung von Bauten}

Die Forschung in dieser Arbeit ist auf die Feststellung der Möglichkeit der Sammlung historischer Daten über die Instandhaltungs - und Verwendungskosten der Bauten der Josip Juraj Strossmayer - Universität in Osijek fokussiert. Es wurden Umfragen und Fragebögen zusammengestellt, in welchen Angaben über die angeführten Kosten sowie Angaben über die Charakteristiken der Bauten und Verwendungsarten in dem definierten Zeitraum gesammelt wurden. Die gesammelten Angaben wurden statistisch bearbeitet und sind in dieser Arbeit dargestellt.

\section{Schlüsselwörter:}

Instandhaltungs - und Verwendungskosten von Bauten, Kostenstruktur, mathematisches Modell,

statistisch wichtige Variablen 


\section{Introduction}

The life cycle costing method was developed in the mid-1960s at the U.S. Department of Defense for the military equipment procurement purposes. The term life cycle costing was used for the first time in 1965 in the report entitled "Life Cycle Costing in Equipment Procurement" [1].

Until recently, the attention of clients, architects and contractors was mainly directed toward reduction of construction costs, and only a few of the stakeholders paid attention to the reduction ofmaintenance and operation costs of buildings and, more importantly, to the reduction of life cycle costs [2]. While architects and planners can refer to various tools for the planning and calculation of construction costs, calculation methods for operating costs are scarce and not very accurate [3]. The life cycle cost - LCC is the total cost of a building or its parts throughout its life, and it includes the costs of planning, design, acquisition, operation, maintenance and disposal, less any residual value [4].

The life cycle costing is one of key elements in public-private partnerships (PPPs) [5]. This fact has made the planning of maintenance and operating costs important already at the design stage of the project.

When considering sustainable development, it is veryimportant to take life cycle costs into account especially because it is estimated that buildings are responsible for 40 per cent of the total energy consumption in European Union [6-8], and most of this energy, 60 per cent, is spent for heating and hot water of households. In Croatia, buildings are responsible for 40 per cent of the total energy consumption,while 70 per cent is spent on heating and hot water [9-10]. All this is especially important in the context of constantly rising demands for energy, and simultaneous reduction of resourcesavailable for energy production.

It has recently been noticed that an increasing attention is being paid to the planning of building maintenance and operationcosts [11]. It has been reported that between $70 \%$ and $85 \%$ ofthe building maintenance and operation costs can be influenced during the design stage,which is a significant part of the total building life cycle costs [12].

Studies conducted in the USA showthat:

- For individual buildings, annual operating costs can exceed $10 \%$ of the original construction costs,

- Non residential operating costs have increased by more than $25 \%$ since 2003 , and

- An average annual cost increase amounts to $4.5 \%$ [13].

Maintenance and repair costs accounted to 37 percent of the total construction-related investments made in 2002 in Sweden [14], while in the UK this percentage was $50 \%$ in 1995 [15].

In order to predict maintenance and operation costs of buildings at the University of Osijek,prediction models have to be developed for those costsfor which such prediction is impossible without establishment of anappropriate dependent and independent database that could be statistically processed.

\section{Previous studies on buildingmaintenance and operation costs}

Maintenance and operation costs are a part of the building'slife cycle costs, i.e. whole life cycle costs. According to ISO 15686:52008, the whole life cycle costs consist of non-constructioncosts, incomes, and life cycle costs (Construction, maintenance and operation costs plus any residual value) [16].

Life cycle cost elements according to ISO 15686:5-2008 are shown in Figure 1. Those costs elements considered as life cycle costs and other costs (non-construction costs and incomes),together with life cycle costs (construction, maintenance and operation costs and residual value),are graphically presented in Figure 1.

It is considered thattwo major obstaclesprevent a broader use of the life cycle cost method. These are the lack of reliable data on historical costs and building operating characteristics, and the absence of effective methods for controlling the cost analysis [17]. The collection and processing of data is extremely difficult because buildings are dissimilar, and are located in different areas, built at different times, and operated by a variety of owners and their agents. Cost data are therefore difficult to collect and analyze, and there is no institutional mechanism or astandard method for collecting and recording of data [11, 17-18].

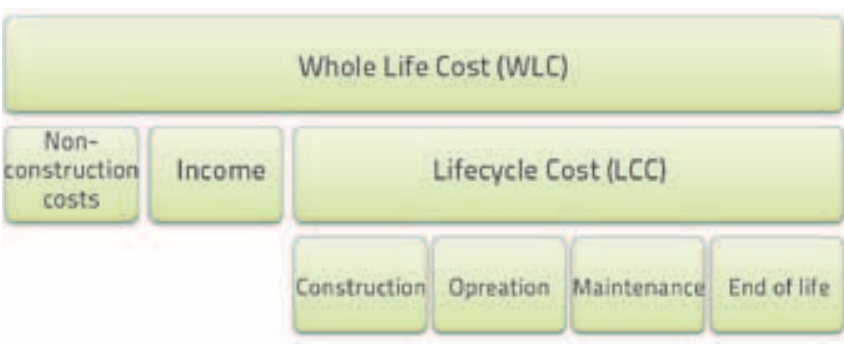

Figure 1. Whole life cycle cost and life cycle cost structure [16]

Maintenance costscover the costoflabor and material, as well as other related costs that are incurred to keep the building or its parts in the state in which it can perform its required functions. Maintenance implies the conduct of corrective, responsive and preventive maintenance activities on constructed assets, or on some parts of these assets. Operation costs includerunning costs and costs of managing the facility or built environment, including administrative support services (e.g. rent, rates, insurances, energy and other environmental/regulatory inspection costs, local taxes and charges) [16]. 
The objectives of building maintenance are:

- to ensure that the buildings and their associated services are in a safe condition,

- to ensure that the buildings are fit for use,

- to ensure that the condition of the building meets all statutory requirements,

- to carry out the maintenance work necessary to maintain the value of physical assets of the building stock, and

- to carry out the work necessary to maintain the quality of the building [19].

According to ISO 15686 there are several types of maintenance:

- preventive maintenance,

- scheduled maintenance,

- corrective maintenance,

- condition-based maintenance,

- emergency/unforeseen maintenance,

- predictive maintenance,

- deferred maintenance and

- on-site/off-site maintenance [16].

The whole life cycle cost structure applied in this paper is shown in Figure $2[2,20]$.

Statutory periodic inspections are various activities that are regulated by relevant laws and regulations, and are conducted to protect safety, health and life of people. These activities consist of tests and inspections that are made on particular building parts, equipment and installations.

Operational facility costs are significant in the life cycle coststructure. Operating costs include energy costs (electricity and heating energy), cost of water supply, waste disposal and IT services,as well as cleaning costs for the facility and its surroundings (e.g., cleaning materials, maids, janitor, etc.).

Preventive maintenance activities consist of works and repairs that are repeated at approximately the same time intervals, depending on the service life of the facility or its structural elements. These activities are conducted to keep the facility in a desired state of repair.

Costs of replacement and repairs are costs of activities that are undertaken to take into account the changes to particular elements, materials and structures.

Reactive maintenance activities are difficult to predict because it is almost impossible to anticipate all possible failures. The number of these activities is large because reactive maintenance activities coverthe cost of repair and replacement of components and materials due to failures and defects.

The data required to carry out the life cycle costing analysis are categorized in Figure 3. These different data influence the life cycle costs at different stages of life cycle [21].

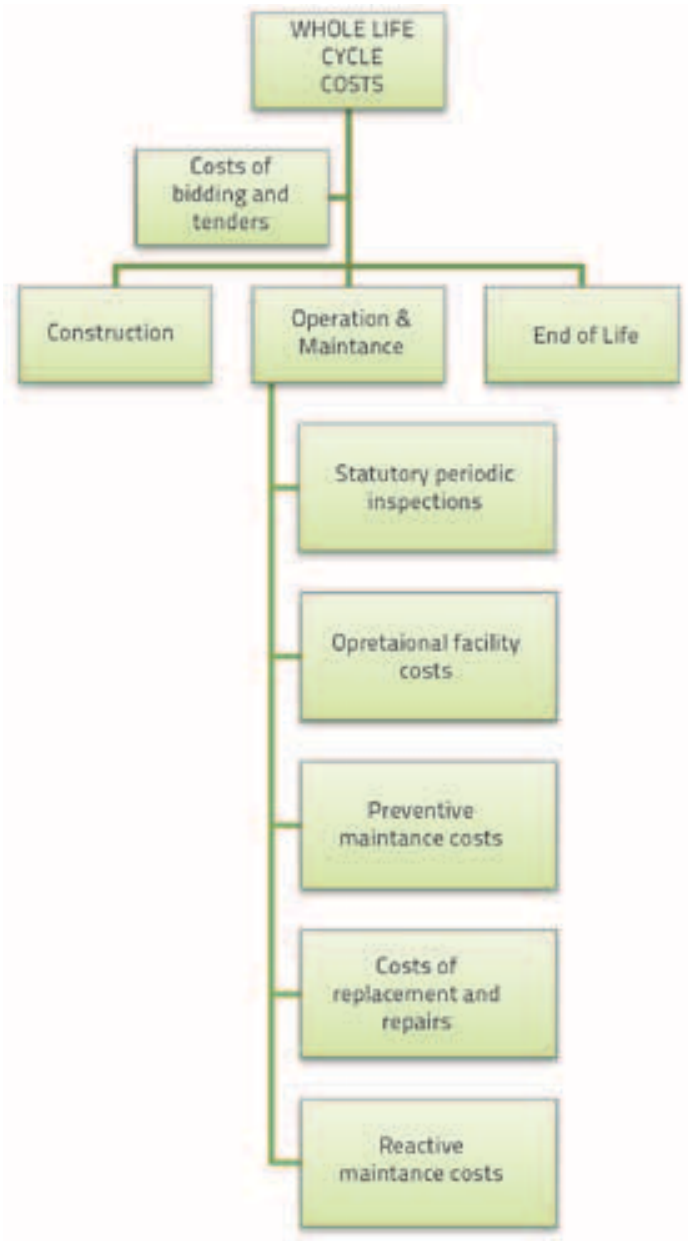

Figure 2 Whole life cycle costs structure $[2,20]$

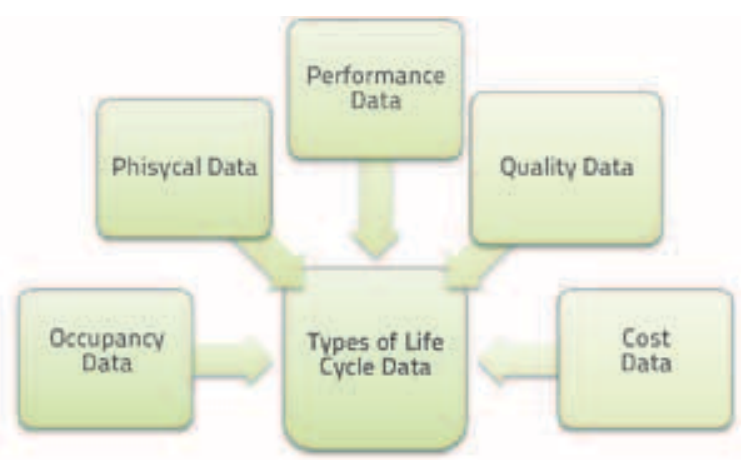

Figure 3. Data required for the life cycle costing analysis [21]

Although a large number of life cycle cost models have been developed over the years, no single life cycle cost model has been accepted as a standard model. Such standard model has not been established for several reasons, including the existence of many different cost data collection systems, and many different types of equipment, devices, or systems [1]. There are two main disadvantages of the existing life cycle cost models or models for estimating maintenance and 
operation costs: low accuracy and restriction to a specific life cycle phase [22]. Various authors take into account different types of costs in their models, which is dependent on the cost structure adopted in this respect.Here, twomodel types can be distinguished. The first type covers cost models in which maintenance and operation costs cannot be extracted, and the second type covers cost models in whichmaintenance and operation costs can easily be extracted.

Some of the existing mathematical models describing life cycle costs are presented below. Several models enable extraction of maintenance and/or operation costs, while others can be usedsolely for predicting maintenance and operation costs. Most of thesemodels are based on the net present value method, the only difference being in the nomenclature and cost structure.

The American Society for Testing and Materials (ASTM 1983) published a model (equation 1) that enables separation of energy costs, and so different discount rates can be applied to reflect different inflation rates [23-24].

$N P V=C+R-S+A+M+E$

where:

$C$ - investment costs

$R$ - life cycle replacement costs

$S$ - the resale value at the end of the study period

$A$ - annually recurring operating, maintenance and repair costs (except energy costs)

$M$-non-annually recurring operating, maintenance and repair costs (except energy costs) and

$E$ - energy costs.

BromilowandPawsey (1987) propose a model (equation 2) according to which costs can be classified into annual recurring costs and non-annual recurring costs [23-25].

$$
N P V=C_{0 i}+\sum_{i=1}^{n} \sum_{t=1}^{T} C_{i t}\left(1+r_{i t}\right)^{-t}+\sum_{j=1}^{m} \sum_{t=1}^{T} C_{i t}\left(1+r_{j t}\right)^{-t}-d \cdot\left(1+r_{d}\right)^{-T}
$$

where:

$C_{0 i} \quad$ - procurement cost at time $\mathrm{t}=0$, including development, design and construction costs, holding charges and other initial charges associated with initial procurement

$C_{i t}$ - annual cost at time $t \quad(0 \leq t \leq T)$ of the function $i(0 \leq i \leq n)$, which can be regarded as continuous over time, such as maintenance, cleaning, energy and security

$C_{j t} \quad$ - cost at time $t$ of the discontinuous support function $j(0 \leq j \leq m)$,such as the repainting or replacement of components at specific time intervals

$r_{i t} \& r_{j t}$-discount rates applicable to support functions $\mathrm{i}$ and $\mathrm{j}_{1}$ respectively

d - value of asset on disposal less costs of disposal,andza troškove uklanjanja

$r_{d} \quad$ - discount rate applicable to asset disposal value.
The main feature of this model is the classification of maintenance activities into non-annual recurring costs, and costs that remain continuous.

Kirkham (2002) et al. proposes the following stochastic model for calculating life cycle costs of hospital buildings [25-26]:

$W L C C=\sum_{n=1}^{i} \frac{F M_{C}+E_{C}+M_{C}+F_{C}+R_{C}}{(1+r)^{i}}$

where:

WLCC - whole life cycle costs

$F M_{c}$ - facilities management costs

$E_{c} \quad$ - energy costs

$M$ - maintenance costs

$F_{\text {c }} \quad$ - financial costs

$R_{c} \quad$ - residual costs

$r \quad$ - discount rate

i - number of years (time)

According to the author of this model the main disadvantage of the model lies in the fact that it can be applied to hospital buildings only [25]. Marenjak et al. developed [2] a model for calculating life cycle cost according to the following expressions:

$$
\begin{aligned}
& U_{T P}=T i_{p}+T f m_{p} \pm T r_{p} \\
& T f m_{p}=\sum_{i=1}^{e} T f m_{e}+\sum_{i=1}^{z} T f m_{z} \\
& T i_{p}=\sum_{i=1}^{e} T i_{e}+\sum_{i=1}^{z} T i_{z}
\end{aligned}
$$

where:

UTP - whole life cycle costs (e.g. hospitals, schools, etc.)

$\mathrm{Ti}_{p} \quad$ - initial (capital) project costs

$\mathrm{Ti}_{z} \quad$ - oother initial costs, e.g. land, design etc.

$\mathrm{Tfm}_{p}$ - facility management costs at the project level

$\mathrm{Tfm} \mathrm{m}_{\mathrm{z}}$ - acility management costs associated with building elements (e.g. insurance costs, cost of electricity, etc.), and

$\operatorname{Tr}_{p} \quad$ - isposal costs at the project level.

According to its data structure and analysis of total project costs, this model allows generation of various project alternatives, and thus minimizes financial and technical risks [2].

The whole life cycle costs of each building element can be calculated for each alternative using the following equation developed by El-Haram et al. (2002) [27-28]:

$$
W L C=C c+\left(\sum_{i=1}^{n}\left(\sum_{j=1}^{m} O c_{j}\right)+\sum_{i=1}^{n}\left(\sum_{j=1}^{m} M c_{j}\right)+\sum_{i=1}^{k} R c_{i}\right) \pm D c
$$

where:

WLC - whole life cycle costs

Cc - construction cost

Oc - operating cost 
Mc - maintenance cost (reactive and preventive)

$R C$ - replacement cost

Dc - disposal cost

$N \quad$ - number of years (expected life of the project or period of analysis

$m$ - number of operating and maintenance tasks and

$k \quad$ - number of replacements.

The above cost model can be used to estimate whole life costs of an individual building element. However, to estimate the WLC of a building, other costs should be added such as the land acquisition, professional fees, bid cost, etc. [27-28].

Unlike the above-presented models, there are those that are solely oriented towards the maintenance and operation costs of buildings. IN 1991, Al-Hajj and Horner conducted the study about maintenance costs of eleven dormitories, six classrooms and three laboratories over the time period of eighteen years, starting from 1972. They came to the conclusion that the cost significant items can be determined by taking into account only those items whose costs are above average. In fact, it was concluded that approximately $15 \%$ of all items account for approximately $85 \%$ of the total maintenance costs. This research shows that historical cost data may be used for developing a model for monitoring and predicting maintenance costs of buildings [29].

This model may be expressed as:

$R_{C}=\frac{1}{C M F} \sum_{i=1}^{n}\left[\left(c_{1}+c_{2}\right)+\left(e_{1}+e_{2}+e_{3}\right)+\left(a_{1}+a_{2}\right)+\left(o_{1}+o_{2}\right)+\left(m_{1}+m_{2}\right)\right](8)$

where:

$R_{c} \quad$ - total running cost

CMF - cost model factor (0.87)

$n \quad$ - time in years

$c_{i}-c_{1}$ expenditure on internal cleaning expenditures, $c_{2}$ laundry expenditures

$e_{i} \quad-e_{1}$ gas, e electricity, $e_{3}$ fuel oil

$o_{i} \quad-o_{1}$ rates, $o_{2}$ insurance

$a_{i} \quad-a_{1}$ management fees, $a_{2}$ security

$m_{i} \quad-m_{1}$ internal decoration, $\mathrm{m}_{2}$ roof repair.

According to the investigation made by Young (1992), the model accuracy specified by the authors lies outside of the expected range.Youngpointed out that these inaccuracies mightbe due to three reasons [23]:

- The data recording system of oneof the sources is different fromother systems used in model development.

- The models do not take accountof different materials or components used in various buildings.

- The occurrence of occasional high cost items.

The first two reasons were mentioned by Al-Hajj (1991) as limitationsof his models. In addition, he employed the moving averagetechnique to account for the third limitation. However, there are four more shortcomings that seem tolimit the generality of these models [23]:
1. The cost-significantrelationships are assumed to be linear, which might not always be the case.

2. Data sets used to develop the models are limited.

3. This procedure ignores some important factors such asthe age, location, level of occupancy, and standards of operation.

4. Historic maintenance data, in terms of time and cost, represent only affordable data, i.e. they do not follow a predefined cost structure.

Regardless of these shortcomings, this is a simple method for predicting building maintenance costs that does not require large sets of data for the prediction of future building maintenance costs [29].

Kirkham et al. (1999) applied regression technique to model the energy cost of sport centers. In the regression models, the floor area and the number of users are two independent inputs. However, its application is limited to that particular cost component. The model has two forms for calculating energy costs $\left(C_{E}\right)$, and these forms can be expressed as [30]:

$C_{E}=1.203+0.97 \cdot$ area

$C_{E}=1.217+0.642 \cdot$ area $+0,206 \cdot$ users

By applying this model,energy costs of sports facilities can be calculated using only two variables, the buildings area and the number of users. Both expressions are used to calculate energy costs, but with different regression coefficients and the number of variables.

The analysis of life cycle cost methods and existing maintenance and operation cost models has revealed the following:

- Maintenance and operation costs represent the most significant part of the building life cycle costs.

- Existing models are usually not based on historical cost records.

- Models founded on historical cost records are mainly developed based on the available cost structure, rather than on the predefined cost structure.

- There are no databases containing records about maintenance and operation costs that could be used for future research to update or improve the existing models.

- There is no framework for the systematization of data.

- There is no simple model for predicting maintenance and operation costs that would be based on building characteristics, policy and user characteristic.

In 2006, the Space Management Group (SMG) conducted research in UK and concluded that academic institutions were unlikely to experience a significant construction in their overall space needs, since reduction in one area was likely to be offset by new demand elsewhere [5]. Therefore, this 
study adopted the assumption that an overall surface area of particular constituents of the Universitywill not be changed over time.

The research was conducted on the existing buildings of the University of Osijek, for which there are no data about construction cost. Most of these buildings are a part of architectural heritage and their removal is not an option. Because of these two facts, this study was focused on building maintenance and operation costs at the University of Osijek, which costs are an integral and very important part of life cycle costs.

Buildings belonging to the University of Osijek are specific because they are located all over the town of Osijek, and their age structure varies from 10 to 300 years. Some parts of ISO 15686 arecurrently adopted in Croatia (parts 1, 2, 3, 5 and 8).

Maintenance and operation costs of University buildings are borne by the public sector and, for that reason, it is very important to predict and optimize these costs in the future with regard to some particular parameters of public buildings:

- low or zero real discount rates, reflecting the particular nature of public works projects, with social rather than investment capital,

- long periods of analysis, and

- low or zero income/revenue flows during life cycle [31].

Buildings at the University of Osijek are special for several additional reasons:

- There are no data about construction cost.

- Most of these buildings are part of architectural heritage and their removal is not an option. Most of the buildings are more than 50 years old.

- They are considered as public buildings whose maintenance and operation are financed from the public budget.

- Buildings are operated in a specific way as they accommodate a large number of users over the year. The exception is a brief period of year characterized by an extremely small number of end users (summer break).

Questionnaires about maintenance and operation costs, general building operation scenario, and operating characteristics, were made in order to define the data base of independent variables (general building and operating characteristics) and dependent variables (maintenance and operation costs) as neededto develop the maintenance and operation cost prediction models. Questionnaires were sent out to all parts of the University in order to collect the above mentioned data in an effective manner. Data were gatheredin the period from 1998 to 2009,according to the life cycle costs structure presented in Figure 2.

This study was conducted to:

- gain insight into the possibility of collecting historical data on maintenance and operation costs of buildings at the University of Osijek,
- obtain data about actual historical maintenance and operation costs of these buildings,

- generate amaintenance and operation cost database,

- identify significant groups of costs within the overall maintenance and operation costs of buildings at the University of Osijek, and

- define statistically significant independent variables required for establishing a mathematical model that could be used for prediction of maintenance and operation costs of buildings at the University of Osijek.

\section{Research methodologies}

The objective of this study was to collect the data aboutmaintenance and operation costsof university buildings overa specific time period, and about operating characteristics of these buildings. The outcomes of the study should provide a background for further research and development of the maintenance and operation cost prediction models at the University of Osijek. Historical records about these costs have been used in some studies for predicting and planning building characteristics or certain types of costs [32-33].

In order to determine significant groups of costs within the overall maintenance and operation costs of buildings, and to establish a relationship between the costs and variables that affect such costs, an appropriate database must be created and used to define the relationship between independent and dependent variables throughregression analysis. The regression analysis enables definition of the analytical mathematical form of the relationship between dependent variables (maintenance and operation costs) and independent variables (e.g. functional surface areas of buildings, age of buildings, time period in which each building is used for University purposes, data about staff and students).

The request to access necessary data for the period from 1997 to 2008 was sent to all University departmentsin order to define the database about maintenance and operation costs, as such database is needed to establish a mathematical model that will be used for prediction of those costs.

The data were collected for the time period of 12 years starting from the year of 1997. This time frame was selected instead of a longer one in order to avoid the costs incurred with respect to war destruction during the period from 1991 to 1995 . The final year for which the costs were analyzed was the year of 2008 because questionnaires were dispatched in2009, and the costs for that year were not accessible. In the mentioned data use request, it was also noted that the datareceived will be used for the purposesof this research only.

The questionnaire and the request that weresent to University departments consisted of 4 parts, namely: 
1. General building characteristics

Data about the age of buildings, the time period in which the building has been used for University purposes, overall surface area, etc.

\section{Facility maintenance plan}

Data about building maintenance plans, facility manager responsible for maintenance, existence of renovation plans, existence of a maintenance strategy, number of users in the future, etc.

\section{Operational characteristics}

Data about the region and area in which buildings are located, total area of buildings, number of shifts, number of users, staff and students, etc.

\section{Maintenance and operation costs}

Maintenance and operation costswere classified in five groups and various cost categories were proposed for each group; respondents were also given the possibility to enter new cost categories if the existing cost categories are insufficient. Data were collected for the following groups of costs:

- Statutory periodic inspections

- Costs of replacing degraded materials and elements

- Costs of periodic works and repairs

- Costs of reactive maintenance and

- Operational costs.

All University departments/sectionsthatwere asked in 2009 to enable access to necessary data are listed in Table 1.

Table 1. Departments/sections of the University of Osijek

\begin{tabular}{|c|c|}
\hline No. & NAME \\
\hline 1. & Faculty of Economics \\
\hline 2. & Faculty of Electrical Engineering \\
\hline 3. & Faculty of Civil Engineering \\
\hline 4. & Catholic Faculty of Theology \\
\hline 5. & Faculty of Medicine \\
\hline 6. & Faculty of Agriculture \\
\hline 7. & University - Rector's Office \\
\hline 8. & Faculty of Law \\
\hline 9. & Faculty of Food Technology \\
\hline 10. & Faculty of Mechanical Engineering \\
\hline 11. & Faculty of Philosophy \\
\hline 12. & Faculty of Education \\
\hline 13. & Department of Mathematics and Physics \\
\hline 14. & Department of Biology and Chemistry \\
\hline 15. & Academy of Arts \\
\hline
\end{tabular}

Data were collected in 2009 and 2010. Some of the entities that submitted the requested data about the university buildings (13 entities or $87 \%$ of all University entities/departments) presentedincomplete data, i.e. cost records were not given at all, or were given for some of the requested cost categories, while some entities delivered only the information about operational characteristics and use policy. After analysis of the data obtained in the survey, the decision was made about which buildings can actually be used in the formation of the database. The essential criterion for enabling entry of data was completeness of information presented in the questionnaires. Finally, $76,92 \%$ of all delivered questionnaires were accepted. The following problems were noted after data collection: in some buildings the activities are performed by two faculties, some faculties have buildings outside of Osijek, and some faculties operate in several buildings across the town.

As this research is related to entire buildings, the first problem was solved by summing up the data regarding costs and average number of users of both faculties, because the information about the functional surface area is the same for both facilities and also, these buildings are viewed as a single facility. The second problem was solved by omitting from the analysis the cost data relating to buildings that are situated outside of Osijek. The third problem was easy to solve because accounting offices were able to provide cost distributionby location of individual faculties. The problem could not be solved in this wayfor two faculty buildings of approximately the same age that are situated next to one another. The solution was found by adding together functional surfaces and number of users of both buildings for which maintenance and operation costs were collected.

After having considered all of the above, as well as the fact that some of the faculties share the same building, it was finally established that eight buildings are suitable for forming the data base about maintenance and operation costs.

Number of years for which thedata were submitted ranged from 4 to12 years. In this paper, this informationis referred to as the reference period. The data structure according to the number of years for which data were obtainedis shown in Figure 4 for eight buildings that were included in the analysis.
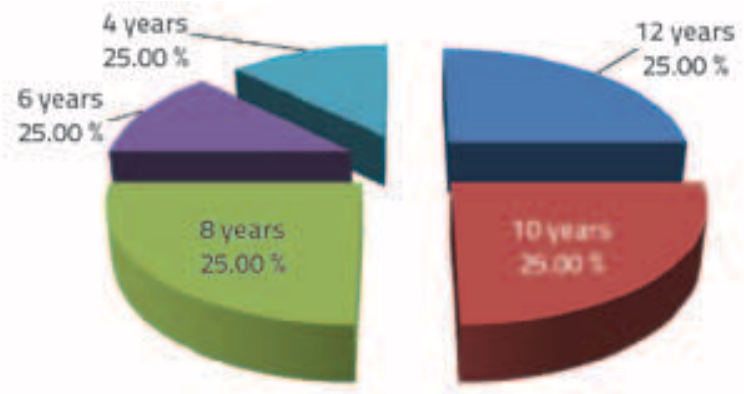

Figure 4. Data structure according to the number of years for which data were obtained

\section{Research results}

Based on the data collected in this survey, the total nominal annual maintenance and operation costs were calculated,and the total maintenance and operation costs over the reference period were defined. 
In order to determine the average nominal annual maintenance and operations costs of university buildings, these total nominal costs were divided by the time period for which the data were obtained (reference period). The same procedure was applied in order to obtainan average number of users (students and staff). Other independent variables (number of shifts, surfaces area of buildings, number of storeys, etc.) did not change during the observed time period. A similar data processing procedure can be found in Al-Hajj thesis [24]

Independent variables were defined based on literature data and past research on similar issues. The independent variables selected in this study can be considered relevant for defining an independent variables database. They are also potential variables for building maintenance and operation costs predicting models. Table 2 presents descriptive statistics and basic statistical measurement of dependent and independent variables.
The first problems that wereencountered during application of regression models in the database analysis are:

- Selection of relevant variables among a large number of independent variables, and

- Such selection of variables frequently causes an apparent correlation between variables, and may lead to the situation in which the number of selected variables exceeds the sample size.

The objective of regression analysis is to create the mathematical model that can be used to predict values of a dependent variable based on values of one or more independent variables [34-35]. The selection of independent variables is one of the most pervasive problems of regression analysis, i.e. efforts have to be made to select independent variables that describe the dependent ones as best as possible, and to keep the model as simple as possible, so as

Table 2. Sample descriptive statistics and list of dependent and potentially independent variables required for defining mathematical model for prediction of maintenance and operation costs for buildings at the University of Osijek

\begin{tabular}{|c|c|c|c|c|c|c|c|c|c|c|c|c|}
\hline $\begin{array}{l}\text { Independent } \\
\text { variables }\end{array}$ & Valid N & Mean & Median & Mode & Minimum & Maximum & Variance & Std.Dev. & Coef.Var. & $\begin{array}{l}\text { Standard } \\
\text { Error }\end{array}$ & Skewness & $\begin{array}{c}\text { Variable } \\
\text { mark }\end{array}$ \\
\hline Building age & 8,00 & 123,00 & 109,00 & Multiple & 10,00 & 293,00 & 9498,86 & 97,46 & 79,24 & 34,46 & 0,92 & var1 \\
\hline $\begin{array}{l}\text { Time period } \\
\text { used for } \\
\text { University } \\
\text { purposes }\end{array}$ & 8,00 & 14,13 & 11,50 & 13,00000 & 4,00 & 33,00 & 88,70 & 9,42 & 66,68 & 3,33 & 1,36 & var2 \\
\hline $\begin{array}{l}\text { Reference } \\
\text { period }\end{array}$ & 8,00 & 8,75 & 9,00 & Multiple & 4,00 & 12,00 & 7,93 & 2,82 & 32,18 & 1,00 & $-0,48$ & var3 \\
\hline $\begin{array}{l}\text { Number of } \\
\text { storeys' }\end{array}$ & 8,00 & 4,00 & 4,00 & Multiple & 3,00 & 5,00 & 0,86 & 0,93 & 23,15 & 0,33 & 0,00 & var4 \\
\hline $\begin{array}{c}\text { Classroom } \\
\text { area }\end{array}$ & 8,00 & 846,67 & 959,47 & Multiple & 284,42 & 1100,00 & 79074,22 & 281,20 & 33,21 & 99,42 & $-1,49$ & var5 \\
\hline $\begin{array}{c}\text { Teachers } \\
\text { cabinets area }\end{array}$ & 8,00 & 735,09 & 747,00 & Multiple & 223,20 & 1169,59 & 85232,62 & 291,95 & 39,72 & 103,22 & $-0,32$ & var6 \\
\hline $\begin{array}{c}\text { Hallways } \\
\text { area }\end{array}$ & 8,00 & 966,29 & 788,50 & Multiple & 140,00 & 2192,76 & 464407,67 & 681,47 & 70,53 & 240,94 & 0,89 & var7 \\
\hline Sanitary area & 8,00 & 222,17 & 160,00 & Multiple & 72,33 & 680,00 & 38945,54 & 197,35 & 88,83 & 69,77 & 2,20 & var8 \\
\hline Office area & 8,00 & 337,08 & 320,77 & Multiple & 139,75 & 755,00 & 36881,70 & 192,05 & 56,97 & 67,90 & 1,61 & var9 \\
\hline Library area & 8,00 & 85,87 & 95,87 & Multiple & 0,00 & 143,65 & 2071,83 & 45,52 & 53,01 & 16,09 & $-0,93$ & var10 \\
\hline $\begin{array}{c}\text { Laboratory } \\
\text { area }\end{array}$ & 8,00 & 471,80 & 448,00 & 0,000000 & 0,00 & 1560,00 & 244964,51 & 494,94 & 104,90 & 174,99 & 1,67 & var11 \\
\hline Other areas & 8,00 & 585,32 & 446,50 & Multiple & 100,00 & 1322,72 & 197803,05 & 444,75 & 75,98 & 157,24 & 0,72 & var12 \\
\hline $\begin{array}{c}\text { Overall } \\
\text { surface area }\end{array}$ & 8,00 & 4315,25 & 4227,00 & Multiple & 2375,00 & 7345,00 & 2194716,21 & 1481,46 & 34,33 & 523,77 & 1,09 & var13 \\
\hline $\begin{array}{l}\text { Avg. number } \\
\text { of staff }\end{array}$ & 8,00 & 90,38 & 73,00 & Multiple & 38,00 & 178,00 & 2918,27 & 54,02 & 59,77 & 19,10 & 1,09 & var14 \\
\hline $\begin{array}{l}\text { Avg. number } \\
\text { of students }\end{array}$ & 8,00 & 788,38 & 583,00 & Multiple & 189,00 & 2540,00 & 547855,13 & 740,17 & 93,89 & 261,69 & 2,35 & var15 \\
\hline $\begin{array}{l}\text { Number of } \\
\text { shifts }\end{array}$ & 8,00 & 1,88 & 2,00 & 2,000000 & 1,00 & 2,00 & 0,13 & 0,35 & 18,86 & 0,13 & $-2,83$ & var16 \\
\hline $\begin{array}{l}\text { Dependent } \\
\text { variables }\end{array}$ & Valid N & Mean & Median & Mode & Minimum & Maximum & Variance & Std.Dev. & Coef.Var. & $\begin{array}{l}\text { Standard } \\
\text { Error }\end{array}$ & $\begin{array}{c}\text { Skewne- } \\
\text { ss }\end{array}$ & $\begin{array}{c}\text { Variable } \\
\text { mark }\end{array}$ \\
\hline $\begin{array}{l}\text { Operating } \\
\text { costs }\end{array}$ & 8,00 & 4,67E+05 & $4,10 E+05$ & Multiple & $3,50 E+05$ & $7,20 E+05$ & $1,95 \mathrm{E}+10$ & $1,39 \mathrm{E}+05$ & 29,87 & 4,93E+04 & 1,26 & var16 \\
\hline $\begin{array}{l}\text { Maint. and } \\
\text { operating } \\
\text { costs }\end{array}$ & 8,00 & $1,12 E+06$ & $8,21 E+05$ & Multiple & $5,86 \mathrm{E}+05$ & $2,18 E+06$ & $4,03 E+11$ & $6,35 E+05$ & 56,89 & $2,24 \mathrm{E}+05$ & 1,03 & var17 \\
\hline
\end{tabular}


not to include independent variables that are not needed to describe certain phenomena [36-37].

When selecting variables, it is important to take into account the fact that only significant variables with minimum prediction error, and the highest coefficient of determination [38],should be selected for the model [36-37].

Since it is unknown which variables are not needed, any selection of variables must be based on the data. In other words, variables are chosen or deleted based on statistics such as p-values (statistical significance) [38]. In this research, multiple regression analysis was applied and stepwise procedure was used in order to determine significant variables of maintenance and operation costs models. The software SAS8.1 was used for this purpose.

The statistical significance, defined at the level of $5 \%$, indicates probability that some other measurement will yield the difference between the new measurement and the sample that is slightly less than $5 \%$ [39-40].The higher the p-value, the less we can believe that the observed relation between variables in the sample is a reliable indicator of the relation between the respective variables in the population [41]. Random sampling from identical population would give difference at same level or less than $95 \%$ of cases and bigger difference would be expected in only $5 \%$ of population.

The statistical significance, defined at the level of $p \leq 0,05$, is considered to be aborderline statistical significance [41-42]. Statistical significances for both cost categories considered in this research are shown below. However, as the statistical significance result may be of little practical importance and applicability [42-43], variables with $p \leq 0.08$ are also consideredif further analysis.

Values given in Tables 3 and 4 are $p$-values and they represent statistical significance of the impact of independent variables on dependent variables [44]. Since it has been established that statistically significant variables exist, the null hypotheses that model has no explanatory power can now be rejected. Nevertheless, it should be noted that in case of variable 14 an average number of staff during the reference period can be considered as "highly" significant due to the p-value of less than 0,001 .

Table 3. Statistically significant variables for the operation cost prediction model

\begin{tabular}{|c|c|c|}
\hline VARIABLE & DESCRIPTION & p-value \\
\hline var. 14 & NUMBER OF STAFF & 0,0006 \\
\hline var. 16 & $\begin{array}{c}\text { NUMBER OF } \\
\text { STUDENTS }\end{array}$ & 0,0381 \\
\hline
\end{tabular}

Table 4. Statistically significant variables for the maintenance and operation cost prediction model

\begin{tabular}{|c|c|c|}
\hline VARIABLE & DESCRIPTION & p-value \\
\hline var. 7 & HALLWAYS AREA & 0,0130 \\
\hline var. 9 & OFFICE AREA & 0,0627 \\
\hline var. 13 & $\begin{array}{c}\text { OVERALL } \\
\text { SURFACE AREA }\end{array}$ & 0,0725 \\
\hline
\end{tabular}

The "Stepwise" procedure allowed analysis of several potential models for calculating and predicting the cost of maintenance and operationof university buildings. These models are shown in Tables 5 and 6, together with their respective coefficients of determination ( $R$-Square Selection Method , $R^{2}$ ) and root mean square error of cross validation ( RMESCV).

Table 5. Proposed variables for the operation cost prediction model

\begin{tabular}{|c|c|c|}
\hline $\begin{array}{c}\text { OPERATIONS COST PREDICTION } \\
\text { MODEL VARIABLES }\end{array}$ & RMSECV & $\mathbf{R}^{2}$ \\
\hline var. 14 & $6,43 \mathrm{E}+04$ & 0,8766 \\
\hline var. 16 & $1,03 \mathrm{E}+05$ & 0,5391 \\
\hline var. 10, var. 14 & $3,54 \mathrm{E}+04$ & 0,9566 \\
\hline var. 14, var. 13 & $4,74 \mathrm{E}+04$ & 0,9373 \\
\hline var. 8, var. 14 & $2,29 \mathrm{E}+04$ & 0,9449 \\
\hline var. 16, var. 14 & $6,70 \mathrm{E}+04$ & 0,9249 \\
\hline var. 5, var. 14 & $8,19 \mathrm{E}+04$ & 0,9035 \\
\hline var. 15, var. 14 & $2,05 \mathrm{E}+05$ & 0,8878 \\
\hline var. 6, var. 14 & $7,09 \mathrm{E}+04$ & 0,8936 \\
\hline var. 11, var. 14, var. 16 & $3,66 \mathrm{E}+04$ & 0,9897 \\
\hline var. 11, var. 13, var. 14 & $3,56 \mathrm{E}+04$ & 0,9867 \\
\hline var. 8, var. 9, var. 14 & $3,82 \mathrm{E}+04$ & 0,9767 \\
\hline
\end{tabular}

Table 6. Proposed variables for the maintenance and operation cost prediction model

\begin{tabular}{|c|c|c|}
\hline $\begin{array}{c}\text { MAINTENANCE AND } \\
\text { OPERATIONS COST PREDICTION } \\
\text { MODEL VARIABLES }\end{array}$ & RMSECV & $\mathbf{R}^{2}$ \\
\hline var. 7 & $4,31 \mathrm{E}+05$ & 0,6697 \\
\hline var. 9 & $5,27 \mathrm{E}+05$ & 0,4647 \\
\hline var. 13 & $5,16 \mathrm{E}+05$ & 0,441 \\
\hline var. 7, var. 15 & $6,13 \mathrm{E}+05$ & 0,8444 \\
\hline var. 1, var. 7 & $4,38 \mathrm{E}+05$ & 0,7046 \\
\hline var. 4, var. 7 & $4,75 \mathrm{E}+05$ & 0,7006 \\
\hline var. 1, var. 7, var. 15 & $5,59 \mathrm{E}+05$ & 0,8951 \\
\hline
\end{tabular}




\section{Conclusion}

The research presented in the paper was conducted in order to analyze themaintenance and operation costs of theOsijek University buildings.This kind of research has so far not been conducted in Croatia. In addition, no data or databases have so far been gathered on the maintenance and operation costs of buildings, especially not to the extent that would actually enable statistical analysis aimed at predicting maintenance and operations costs of public buildings. The data were gatheredbased on a questionnaire that was sent to alluniversity departments/entities. The respondents were asked to supplygeneral data about the operation and characteristicsof university buildings, and the data on the maintenance and operation costs, according to a pre-defined cost data structure.

It was established during the research that the necessary data can be collected using the methodology applied to this purpose. The research resulted increation of a database with dependent variables, maintenance and operations costs, and independent variables, building characteristics and operational characteristics, which are statistically significant for predicting maintenance and operation costs using theprediction models of the University of Osijek facilities, based on the stepwise procedure.

Further research should focus on creating the maintenance and operation cost prediction models of the University of Osijek facilities, and this by means of statistical methods. By defining the model for calculating maintenance and operation costs, the cost model variables would also be defined. Consequently, it would be possible to definecharacteristics of buildings and their operational properties, which affect the maintenance and operation costs,as well as the information that is needed in the design of new buildings of similar purpose. By applying models obtained according to the above recommendations,it will be possible to plan and predict the maintenance and operation costs of university buildings for certain time periods, both at the university level and at the level of individual buildings.

\section{REFERENCES}

[1] Dhillon, B.S., Life Cycle Costing for Engineers. 2010, Boca Raton, USA: Taylor \& Francis Group.

[2] Marenjak, S., El-Haram, M.A. \& Horner, R.M.W. : Procjena ukupnih troskova u visokogradnji, Gradevinar, 2002. 54: p. 393401.

[3] Biondini, F. \& Frangopol, D.M.: Proceedings of the first international symposium on life-cycle civil engineering. The first international symposium on life-cycle civil engineering. 2008. Varrena, Lake Como, Italy: Taylor \& Francis Group, London, UK.

[4] Langdon, D. and M. Consulting, Life Cycle Costs in Construction, Final Report. 2003: London, United Kingdom.

[5] Atkin, B. and A. Brooks, Total Facilities Management. Vol. 3. 2009, Singapore: Wiley-Blackwell. 305.

[6] Borković, Ž.H. i dr.: Pilot-projekt povećanja EE u zgradarstvu. 2003., Energetski institut Hrvoje Požar; MZOPU;.

[7] Borković, Ž.H.: EU Direktiva o energetskim karakteristikama zgrada 2002/91/EC. 2005, Energetski institut Hrvoje Požar.

[8] Khamidi, M.F., O.A. Lateef, and A. Idrus, Building Maintenance: $A$ path towards sustainability. Malaysian Construction Research Journal, 2010. 7.

[9] Čulo, K. \& Krstić, H.: Cost benefit analysis of energy efficient family houses, in Second International Conference on Harminisation Between Architecture and Nature, Eco-Architecture 2008. 2008: Algarve, Portugal.

[10] Krstić, H. \& Čulo, K.: Cost efficiency comparison of classic and solar house, in Quality, environment, health protection and safety managememnt development trends. 2008: Neum, Bosna i Hercegovina.
[11] Sterner, E.: Life-cycle costing and its use in the Swedish building sector. Building Research \& Information, 2000. 28.

[12] Asiedu, Y. and P. Gu, Product life cycle cost analysis: state of the art review. International Journal of Production Research, 1998. 36(4).

[13] Miller, J., Facility Operations Cost Trends and the MARS 8 Life Cycle Cost Model. 2008, Whitestone Briefings: Washington, D.C.

[14] Sterner, E.: "Green procurement" of buildings: a study of Swedish clients considerations Construction Management and Economics, 2002. 20

[15] DZNM, Zgrade i druge građevine - Planiranje vijeka uporabe 1. dio: Opća načela (ISO 15686-1:2000). 2002, Zagreb: Državni zavod za normizaciju i mjeriteljstvo.

[16] ISO, Buildings and constructed assets - Service life planning Part 5: Life cycle costing. 2004.

[17] Ren, G. \& Zhang, Q.: Benchmarking the Life Cycle cost Management of Building Project, in International Conference on Intelligent Systems and Knowledge Engineering (ISKE 2007). 2007: China.

[18] El-Haram, M.A. \& Horner, M.W.: Factors affecting housing maintenance cost. Journal of Quality in Maintenance Engineering, 2002. 8.

[19] Horner, R.M.W., El-Haram, M.A. \& Munns, A.K.: Building maintenance strategy: a new management approach. Journal of Quality in Maintenance Engineering, 1997. 3.

[20] Marenjak, S.: Javno-privatno partnerstvo. 2011., Ekonomski fakultet: Zagreb. 
[21] Levander, E., J. Schade, \& Stehn, L.: Life cycle costing for buildings: theory and suitability for addressing uncertainties about timber housing. 2009.

[22] Liu, H., et al., Regression models for estimating product life cycle cost. J Intell Manuf, 2009. 20.

[23] Kishk, M., et al.: Whole life costing in construction, A state of the art review. 2003.

[24] Al-Hajj, A.N.: Simple cost-significant models for total life-cycle costing in buildings, in Department of Civil Engineering. 1991, University of Dundee: Kirkcaldy.

[25] Kirkham, R.J.: A stochastic whole life cycle cost model for a National Health Service acute care hospital building, in Department of Architecture and Building Engineering, Faculty of Social and Environmental Studies, University of Liverpool. 2002.

[26] Boussabaine, A.H. \& Kirkham, R.J.: Whole life cycle performance measurement re-engineering for the UK National Health Service estate. Facilities, 2006. 24.

[27] El-Haram, M.A., Marenjak, S. \& Horner, R.M.W.: Development of a generic framework for collecting whole life cost data for the building industry. Journal of Quality in Maintenance Engineering, 2002. 8.

[28] Marenjak, S., El-Haram, M.A. \& Horner, R.M.W.: Whole Life Costing in the Building Industry: A Case Study, in Construction in the XXI Century: Local and Global Challenges, Joint 2006 CIB Symposium. 2006: Rome.

[29] Al-Hajj, A. \& Horner, M.W.: Modelling the running costs of buildings. Construction Management and Economics, 1998. 16: p. 459-470.

[30] Consulting, D.L.M.: Life cycle costing (LCC) as a contribution to sustainable construction: a common methodology, Final Review 2007: London.

[31] Consulting, D.L.M.: Life cycle costing (LCC) as a contribution to sustainable construction, Final Guidance 2007: London.
[32] Aziz, A.M.A.: Performance Analysis and Forecasting for WSDOT Highway Projects. 2007, Washington State Transportation Center (TRAC): Washington.

[33] Cheung, F.K.T. \& Skitmore, M.: Application of cross validation techniques for modelling construction costs during the very early design stage Building and Environment 2005. 41(12): p. 1973-1990.

[34] Buljan-August, M., Pivac, S. \& Štambuk, A.: Upotreba statistike u ekonomiji. 2007., Rijeka: Ekonomski fakultet Sveučilišta u Rijeci.

[35] Amemiya, T.: Introduction to Statistics and Econometrics. 1994, London: Harvard Univeristy Press.

[36] Montgomery, D.C.: Design and Analysis of Experiments. 2001, New York: John Wiley \& Sons, Inc.

[37] Baumann, K.: Cross-validation as the objective function for variable-selection techniques. Trends in Analytical Chemistry, 2003. 22(6).

[38] Freund, R.J., Wilson, W.J.\& Sa, P.: Regression Analysis Statistical Modeling of a Response Variable. 2006, London: Elsevier Inc.

[39] Petz, B., Osnovne statističke metode za nematematičare. 2004., Zagreb: Naklada Slap.

[40] StatSoft. Electronic Statistics Textbook. 2010 12/2010]; Available from: http://www.statsoft.com/textbook/partialleast-squares/.

[41] Elementary Concepts in Statistics. 2011, StatSoft, Inc.: Tulsa.

[42] Studenmund, A.H.: Using Econometrics: A Practical Guide 2000: Addison Wesley.

[43] Tiljak, M.K. \& Ivanković, D.: Testiranje hipoteze. 2011 08/2011]; Available from: http://cms.mef.hr/.

[44] Vukelić, A. i Kljusurić, J.G.: Napredne statističke metode za analizu podataka. 2009 01/2010]; Available from: http:// www.pbf.hr/hr/zavodi/zavod_za_procesno_inzenjerstvo/ primjenjena_analiza_podataka. 